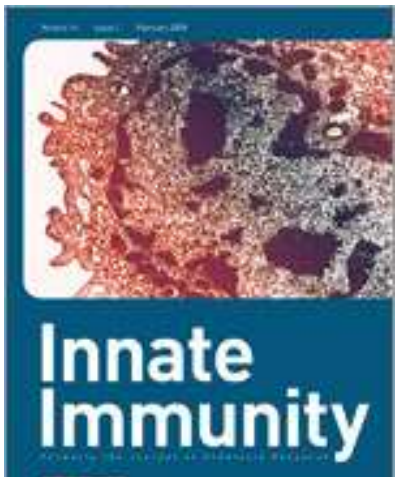

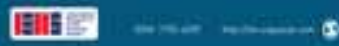

\title{
Paracellular permeability is increased by basal lipopolysaccharide in a primary culture of colonic epithelial cells; an effect prevented by an activator of Toll-like receptor-2
}

\begin{tabular}{|c|c|}
\hline Journal: & Innate Immunity \\
\hline Manuscript ID: & Draft \\
\hline Manuscript Type: & Original Manuscript \\
\hline \multicolumn{2}{|l|}{$\begin{array}{r}\text { Date Submitted by the } \\
\text { Author: }\end{array}$} \\
\hline Complete List of Authors: & $\begin{array}{l}\text { Hanson, Peter; Aston University, Life \& Health Sciences } \\
\text { MORAN, ANTHONY; National University of Ireland, Microbiology } \\
\text { Butler, Kate; Aston University, Life \& Health Sciences }\end{array}$ \\
\hline Keywords: & $\begin{array}{l}\text { colon, lipopolysaccharide, permeability, Toll-like receptor, primary } \\
\text { culture }\end{array}$ \\
\hline Abstract: & $\begin{array}{l}\text { Lipopolysaccharide (LPS), which generally activates Toll-like } \\
\text { receptor } 4 \text { (TLR-4), is expressed on commensal colonic bacteria. In } \\
\text { a number of tissues, LPS can act directly on epithelial cells to } \\
\text { increase paracellular permeability. Such an effect in the colon would } \\
\text { have an important impact on the understanding of normal } \\
\text { homeostasis and of pathology. Our aim was to use a novel primary } \\
\text { culture of colonic epithelial cells grown on Transwells to investigate } \\
\text { whether LPS, or Pam3CSK4, an activator of Toll-like receptor-2 } \\
\text { (TLR-2), affected paracellular permeability. Consequently, [14C] } \\
\text { mannitol transfer and transepithelial electrical resistance (TEER) } \\
\text { were measured. The preparation consisted primarily of cytokeratin- } \\
18 \text { positive epithelial cells that produced superoxide, stained for } \\
\text { mucus with periodic acid-Schiff reagent, exhibited alkaline } \\
\text { phosphatase activity and expressed TLR-2 and TLR-4. Tight } \\
\text { junctions and desmosomes were visible by transmission electron } \\
\text { microscopy. Basally, but not apically, applied LPS from Escherichia }\end{array}$ \\
\hline
\end{tabular}




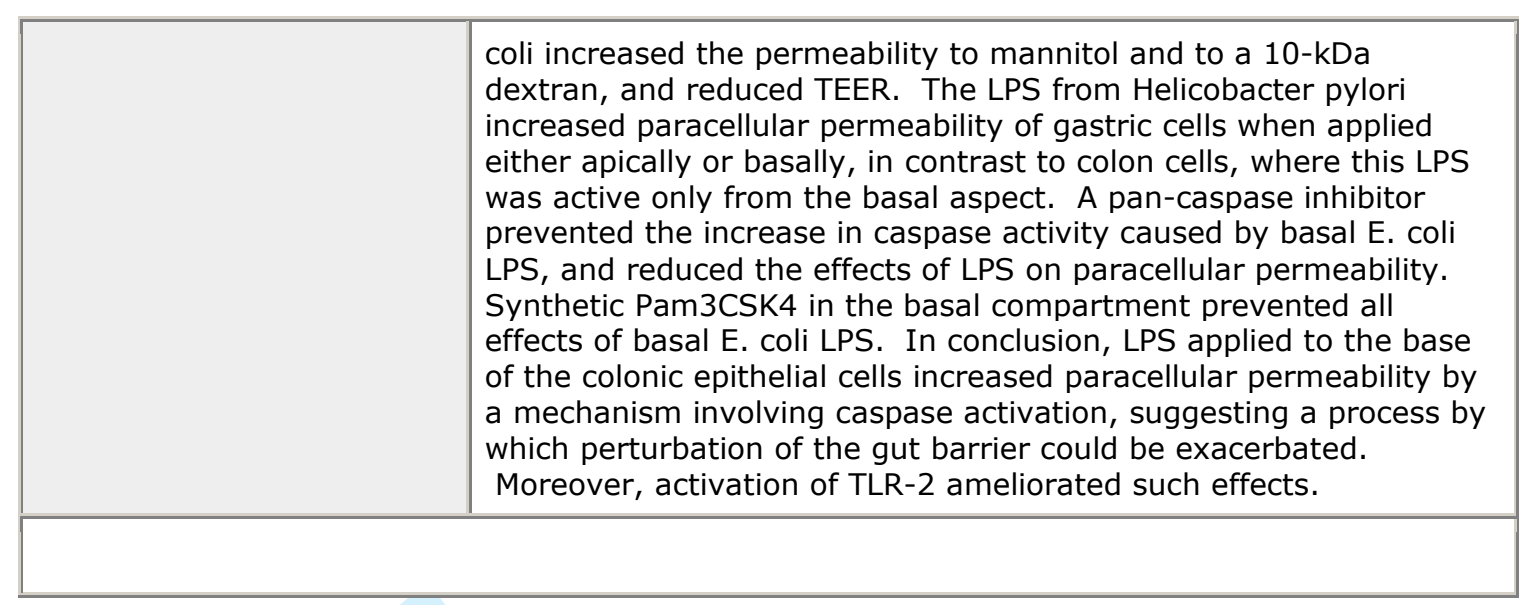

\section{(5) ScholaronE \\ Manuscript Central}




\section{ABSTRACT}

Lipopolysaccharide (LPS), which generally activates Toll-like receptor 4 (TLR-4), is expressed on commensal colonic bacteria. In a number of tissues, LPS can act directly on epithelial cells to increase paracellular permeability. Such an effect in the colon would have an important impact on the understanding of normal homeostasis and of pathology. Our aim was to use a novel primary culture of colonic epithelial cells grown on Transwells to investigate whether LPS, or $\mathrm{Pam}_{3} \mathrm{CSK}_{4}$, an activator of Toll-like receptor-2 (TLR-2), affected paracellular permeability. Consequently, $\left[{ }^{14} \mathrm{C}\right]$ mannitol transfer and transepithelial electrical resistance (TEER) were measured. The preparation consisted primarily of cytokeratin-18 positive epithelial cells that produced superoxide, stained for mucus with periodic acid-Schiff reagent, exhibited alkaline phosphatase activity and expressed TLR-2 and TLR-4. Tight junctions and desmosomes were visible by transmission electron microscopy. Basally, but not apically, applied LPS from Escherichia coli increased the permeability to mannitol and to a 10-kDa dextran, and reduced TEER. The LPS from Helicobacter pylori increased paracellular permeability of gastric cells when applied either apically or basally, in contrast to colon cells, where this LPS was active only from the basal aspect. A pan-caspase inhibitor prevented the increase in caspase activity caused by basal E. coli LPS, and reduced the effects of LPS on paracellular permeability. Synthetic $\mathrm{Pam}_{3} \mathrm{CSK}_{4}$ in the basal compartment prevented all effects of basal $E$. coli LPS. In conclusion, LPS applied to the base of the colonic epithelial cells increased paracellular permeability by a mechanism involving caspase activation, suggesting a process by which perturbation of the gut barrier could be exacerbated. Moreover, activation of TLR-2 ameliorated such effects.

Keywords: Colon, Lipopolysaccharide, Permeability, Toll-like receptor, Primary culture 


\section{INTRODUCTION}

A single layer of colonic epithelial cells, linked together by tight and adherens junctions, forms the barrier that prevents access of the enteric bacterial flora into the internal host tissues. Importantly, perturbation of the gut barrier is increasingly being linked with disease. Thus, in both Crohn's disease ${ }^{1-3}$ and in ulcerative colitis, ${ }^{4}$ there is increased permeability through tight junctions and in Crohn's disease changes in permeability may predict relapse. ${ }^{5}$ A current view is that the cytokines released into the mucosa in these inflammatory bowel diseases activate signalling pathways that ultimately effect changes in the tight junctions. ${ }^{6-8}$

Cytokine release may be caused by pathogen-associated molecular patterns (PAMPs) such as lipopolysaccharide (LPS) which, for example, induces release of tumour necrosis factor-alpha (TNF- $\alpha$ ) from macrophages. Generally, the cellular receptor for LPS is Toll-like receptor-4 (TLR-4). In the gut, messenger RNA (mRNA) for TLR-4 is present not only in macrophages but has been found in highly purified colonic epithelial cells from humans ${ }^{9,10}$ and mice, ${ }^{11}$ as has TLR-4 protein. ${ }^{11,12}$ In lung, ${ }^{13}$ corneal $^{14}$ and cholangiocyte ${ }^{15}$ epithelial cells LPS directly increases paracellular permeability. We therefore hypothesized that LPS might act directly on colonic epithelial cells to increase paracellular permeability. A further issue is that since epithelial cells border the gut lumen, the presence of TLR-4 must be reconciled with normal homeostasis in the presence of commensal bacteria, many of which are Gram-negative, and thus will express LPS. Recent suggestions are an intracellular location of TLR-4, ${ }^{16}$ sequestration of TLR-4 into crypts ${ }^{17}$ and the influence of regulation of TLR-4 signalling. ${ }^{18}$ Alternatively, expression of TLR-4 protein may normally be low, but be increased in pathological conditions such as Crohn's disease 
and ulcerative colitis. ${ }^{12}$ A further possibility, which is investigated here, is that responses of colonic epithelial cells might be polarized, whereby any effect of LPS applied to the apical lumen-facing aspect differs from that of LPS applied to the basal aspect.

Toll-like receptor 2 (TLR-2) mRNA has been detected in human and mouse colonic epithelial cells ${ }^{10,11}$, as has the protein in mouse colonic epithelial cells. ${ }^{11}$ Effects of TLR-2 can be investigated by using the synthetic TLR-2 ligand, $N$ palmitoyl-S-[2,3-bis(palmitoyloxy)-(2RS)-propyl]-(R)-cysteinyl-(S)-seryl-(S)-lysyl(S)lysyl-(S)-lysyl-(S)-lysine (Pam $\left.{ }_{3} \mathrm{CSK}_{4}\right)$. In Caco-2 cells this ligand produced a transient increase in transepithelial electrical resistance (TEER), which was associated with a redistribution of the tight junction-associated protein ZO-1. ${ }^{19}$ Consequently, we have investigated the effects of $\mathrm{Pam}_{3} \mathrm{CSK}_{4}$ on colonic cells in the presence and absence of LPS.

Investigations of the effects of LPS using adenocarcinoma cell lines is problematic possibly because of the low expression of TLR- $4^{20}$ or of accessory proteins needed for receptor activation. For example, LPS does not affect TEER in Caco-2 cells, ${ }^{19}$ and Caco-2 cells produced very little interleukin-8 (IL-8) in response to LPS. ${ }^{20}$ Thus, we decided to build on our experience of primary culture of guinea pig gastric cells on Transwells ${ }^{21,22}$ to develop a preparation using colonic epithelial cells in which the effects of LPS on paracellular permeability could be explored by the apical to basal transfer of mannitol, and from measurement of TEER. As described herein, we find that basally, but not apically applied, LPS increases permeability and that this effect is inhibited by a pan-caspase inhibitor and by the synthetic TLR-2 ligand $\mathrm{Pam}_{3} \mathrm{CSK}_{4}$. 


\section{MATERIALS AND METHODS}

\section{Animals and materials}

Dunkin-Hartley guinea pigs of 200-300g were obtained from Harlan UK, Bicester, Oxon. All experimental work complied with the UK Animals (Scientific Procedures) Act 1986 and had been approved by the Aston University Bioethics committee. The LPS of Escherichia coli 0111:B4 was obtained from Sigma (Poole, UK). Helicobacter pylori LPS was prepared from the type strain (NCTC 11637) as described previously. ${ }^{23}$ Synthetic $\mathrm{Pam}_{3} \mathrm{CSK}_{4}$ was obtained commercially (InvivoGen, San Diego, USA), and dissolved in sterile, endotoxin-free water before use. $\mathrm{N}$ benzyloxycarbonyl-Val-Ala-Asp(OMe) fluoromethyl ketone (Z-VAD-FMK) was obtained from R\&D systems (Abingdon, UK). Unless otherwise stated, all other reagents including antibodies were obtained from Sigma.

\section{Primary culture of colonic cells}

Guinea pigs were anaesthetized with intramuscularly delivered Hypnorm (Janssen, Oxford, UK) at a dose of $1 \mathrm{ml} / \mathrm{kg}$, and with intraperitoneal diazepam (3.75 mg/kg). The colon was removed from the rectum to a point $5 \mathrm{~cm}$ from the caecum. Subsequently, colonic mucosa was scraped from the muscle, minced with fine scissors, and incubated for 20 min in Dulbecco's Modified Eagle Medium:F12 Nutrient mixture, 1:1 (DMEM:F12, Invitrogen, Paisley, UK), containing bovine serum albumin $(2 \mathrm{~g} / \mathrm{l})$, gentamicin $(50 \mu \mathrm{g} / \mathrm{ml})$, amphotericin $\mathrm{B}(2.5 \mu \mathrm{g} / \mathrm{ml})$, and pronase $\mathrm{E}$ $\left(0.5 \mathrm{mg} / \mathrm{ml}\right.$, Merck, Lutterworth, UK) at $37^{\circ} \mathrm{C}$ with shaking (120 cycles $\left./ \mathrm{min}\right)$ in a mixed atmosphere of $\mathrm{O}_{2}: \mathrm{CO}_{2}(95 \%: 5 \%)$. After centrifugation for $2 \min \left(200 \times \mathrm{g}, 15^{\circ} \mathrm{C}\right)$, the pellet was incubated with the same medium for $20 \mathrm{~min}$, except that collagenase type 
I $(0.4 \mathrm{mg} / \mathrm{ml})$ replaced pronase. The digest was filtered through nylon mesh (150 $\mu \mathrm{m})$, again centrifuged for $2 \mathrm{~min}\left(100 \times \mathrm{g}\right.$ and $\left.15^{\circ} \mathrm{C}\right)$, and resuspended in culture medium composed of DMEM:F12 containing foetal calf serum (10\% v/v), penicillin (100 u/ml), streptomycin $(100 \mu \mathrm{g} / \mathrm{ml})$, amphotericin B $(2.5 \mu \mathrm{g} / \mathrm{ml})$, epidermal growth factor from mouse sub-maxillary glands $(20 \mathrm{ng} / \mathrm{ml})$, recombinant human insulin (10 $\mu \mathrm{g} / \mathrm{ml})$ and hydrocortisone 21 -hemisuccinate $(150 \mathrm{nmol} / \mathrm{l})$. After a further centrifugation $\left(75 \times \mathrm{g}, 15^{\circ} \mathrm{C}, 2 \mathrm{~min}\right)$, the pellet, which comprised crypt fragments ( $\geq$ 20 cells) and single cells, was resuspended in culture medium (at 24,000 crypt fragments $/ \mathrm{ml})$. The suspension $(0.5 \mathrm{ml})$ was added onto Transwell membranes (12 $\mathrm{mm}$ diameter, polycarbonate membrane, $0.4 \mu \mathrm{m}$ pore size) supplied by Corning (Appleton Woods, Birmingham, UK) which had been coated with collagen IV from human placenta. ${ }^{21}$ Culture medium $(1.5 \mathrm{ml})$ was present in the basal compartment. Media were changed after 1, 3 and 6 d of culture using culture medium with serum reduced from $10 \%$ to $4 \%(\mathrm{v} / \mathrm{v})$. Experiments were performed eight days after culture was initiated.

Viability of cells at the end of a $5 \mathrm{~h}$ experiment was assessed by replacing the basal medium 30 min before termination with one which was identical except for the presence of the cell permeable nuclear stain bisbenzimide $(\mathrm{H} 33258,5 \mu \mathrm{g} / \mathrm{ml})$ and the normally cell membrane impermeant propidium iodide (Pl, $2 \mu \mathrm{g} / \mathrm{ml}$ ). After $30 \mathrm{~min}$ Transwell membranes were removed, mounted in phosphate-buffered saline (PBS), and examined under a fluorescence microscope with successively uv and green illumination. Damaged cells were identified as those with nuclei exhibiting both blue (H33258) and red (PI) fluorescence.

Paracellular permeability and TEER of colonic cells 


\section{D-[1- $\left.{ }^{14} \mathrm{C}\right]$ Mannitol (GE Healthcare, Little Chalfont, UK) was introduced $(0.9 \mu \mathrm{Ci} / \mathrm{ml}$} $15.5 \mu \mathrm{mol} / \mathrm{l})$ into the apical compartment, and medium from the lower compartment was removed after $1 \mathrm{~h}$ for estimation of mannitol transfer by scintillation counting. This basal measurement was performed on all Transwells and was used for normalization. Subsequently, reagents were added to apical and basal compartments as required and transfer of Transwells to new basal medium was made at times determined by the experimental design. Apparent permeability $\left(P_{\text {app }}\right)$ to mannitol was calculated as described by Tavelin et al. ${ }^{24}$ Fluorescein isothiocyanate- (FITC-) labelled dextran $10 \mathrm{kDa}$ (FD10) was present in the apical compartment $(1 \mathrm{mg} / \mathrm{ml})$, and its presence in the basal compartment was measured by using a fluorescence plate reader (Molecular Devices, Sunnyvale, CA) with excitation at $485 \mathrm{~nm}$, emission at $530 \mathrm{~nm}$ and cut-off at $515 \mathrm{~nm}$. At the beginning and the end of experiments TEER was measured by using an EVOM voltohmmeter (World Precision Instruments, Sarasota, FI, USA) and chopstick electrodes as described previously. ${ }^{21}$

\section{Gastric epithelial cells}

Culture of gastric cells and measurement of TEER and paracellular permeability was as described in detail previously. ${ }^{21}$ Briefly, cells were isolated from minced guinea pig gastric mucosa by sequential digestion with pronase and collagenase, and after centrifugation, suspended in RPMI 1640 medium containing foetal calf serum (10\% $\mathrm{v} / \mathrm{v})$, penicillin $(100 \mathrm{u} / \mathrm{ml})$, streptomycin $(100 \mu \mathrm{g} / \mathrm{ml})$, amphotericin $B(2.5 \mu \mathrm{g} / \mathrm{ml})$ and epidermal growth factor from mouse sub-maxillary glands $(20 \mathrm{ng} / \mathrm{ml})$ at $10^{6} \mathrm{cells} / \mathrm{ml}$. The suspension $(0.5 \mathrm{ml})$ was added to Transwell membranes $(12 \mathrm{~mm}$ diameter, polycarbonate membrane, $0.4 \mu \mathrm{m}$ pore size), which had been coated with collagen 
IV, and cultured for $3 \mathrm{~d}$, after which time the cells were fully confluent and were used for experiments.

\section{Culture of Caco-2 cells}

Caco-2 cells, obtained from the American Type Culture Collection (ATCC, Rockville, MD), were plated on polycarbonate Transwells at $2 \times 10^{5}$ cells $/ \mathrm{cm}^{2}$ and were grown in DMEM containing heat-inactivated foetal calf serum $(10 \% \mathrm{v} / \mathrm{v})$, penicillin $(100 \mathrm{u} / \mathrm{ml})$ and streptomycin $(100 \mu \mathrm{g} / \mathrm{ml})$ for 21 days at $37^{\circ} \mathrm{C}$ in $5 \% \mathrm{CO}_{2}$ in air.

\section{Histochemistry}

To obtain vertical sections through Transwell preparations they were fixed for 10 min at room temperature in $4 \%(\mathrm{w} / \mathrm{v})$ paraformaldehyde in PBS, washed in PBS at $4{ }^{\circ} \mathrm{C}$, and then infiltrated with a $10 \%(\mathrm{w} / \mathrm{v})$ solution of gelatin (bloom number 300$)$ for 15 min at $37^{\circ} \mathrm{C}$. Membranes were stacked, cooled to $4^{\circ} \mathrm{C}$, embedded in OCT (optimal cutting temperature) compound and frozen in liquid nitrogen. Sections (10 $\mu \mathrm{m})$ were cut using a cryostat (Bright, Huntingdon, UK) and transferred to slides coated previously with gelatin $(0.1 \% \mathrm{w} / \mathrm{v})$ and chromium potassium sulphate $(0.01 \% \mathrm{w} / \mathrm{v})$. The use of gelatin enabled the retention of sections on the Transwell membrane and on the microscope slide. Alternatively, cells were detached from Transwells by using trypsin/ethylenediamine tetraacectic acid (EDTA) fixed in 4\% (w/v) paraformaldehyde in PBS and transferred to microscope slides by using a Cytocentrifuge (Shandon, UK). Sections were stained with conventional haematoxylin and eosin stain, periodic acid-Schiff reagent ${ }^{21}$, or alkaline phosphatase by soaking in PBS containing Tween$20(0.2 \% \mathrm{v} / \mathrm{v})$ for $10 \mathrm{~min}$, rinsing in PBS and incubating with Tris buffer $(0.1 \mathrm{M}, \mathrm{pH}$ 8.8) containing Fast Red TR ( $1 \mathrm{mg} / \mathrm{ml})$ and Napthol AS-MX phosphate $(0.5 \mathrm{mg} / \mathrm{ml})$ 
for $30 \mathrm{~min}$ at room temperature. Nuclei were stained with 4', 6'-diamidino-2-phenyl indole dihydrochloride (DAPI, $2 \mu \mathrm{g} / \mathrm{ml}$ ).

\section{Fluorescence immunocytochemistry}

Transwell membranes were fixed in 4\% (w/v) paraformaldehyde in PBS and they, or cytocentrifuge preparations, were permeabilized by incubation in Triton X-100 $(0.1 \%$ v/v) in PBS for 10 min. After blocking with serum from the appropriate species (10\% $\mathrm{v} / \mathrm{v}$ ) in PBS for $1 \mathrm{~h}$, samples were incubated with either mouse anti-cytokeratin-18, (clone CY-90) monoclonal antibody (Mab), 1:400; mouse anti-human macrophages (clone MAC 387) Mab, 1:100 (Serotec Oxford, UK); mouse anti- $\alpha$ smooth muscle actin (clone 1A4) Mab, 1:400; or goat anti-vimentin antibody, 1:20 for $1 \mathrm{~h}$ at room temperature. Incubation with the appropriate conjugated secondary antibodies (FITClabelled goat anti-mouse IgG, 1:64; FITC-conjugated rabbit anti-goat IgG, 1:400; and tetramethyl rhodamine-labelled goat anti-mouse IgG, 1:128) was for $1 \mathrm{~h}$ at room temperature; after which preparations were washed and mounted in Vectashield hard set (Vector laboratories, Peterborough, UK). Negative controls were obtained by omitting the primary antibody. Counting of apoptotic nuclei on Transwell membranes was performed using a Zeiss AxioCam HRc digital camera (Jena, Germany) with a x40 objective, by capturing six successive fields moving in from the edge of the filter, coding the output, and then counting total and apoptotic nuclei (which were characterized by condensation and fragmentation of chromatin). Confocal images were obtained with a Zeiss LSM 510 confocal microscope.

\section{Electron microscopy}


Transwell membranes were fixed for $1 \mathrm{~h}$ at room temperature in glutaraldehyde $(2.5 \% \mathrm{v} / \mathrm{v})$ in sodium cacodylate buffer $(0.1 \mathrm{M}, \mathrm{pH} 7.4)$. Samples were post-fixed in osmium tetroxide $(1 \% \mathrm{w} / \mathrm{v})$ in the same buffer, dehydrated and embedded in LR white resin (Agar Scientific, Essex, UK). Sections, approximately $70 \mathrm{~nm}$ thick, were stained with ethanolic uranyl acetate and Reynold's lead citrate, before observation in a Jeol 1200 EXII transmission electron microscope.

\section{Immunoblotting}

Transwell membranes were rapidly extracted with $100 \mu$ l of electrophoresis sample buffer at $95^{\circ} \mathrm{C}$ in a microfuge tube and then maintained at this temperature for $3 \mathrm{~min}$. Samples were sonicated at an amplitude of $10 \mu \mathrm{m}$ for $10 \mathrm{~s}$. After sodium dodecyl sulphate polyacrylamide gel electrophoresis and transfer of separated proteins to polyvinylidene difluoride (PVDF) membranes, immunoblotting was initiated by incubation with blocking solution (defatted milk powder $5 \% \mathrm{w} / \mathrm{v}$ ) in Tris-buffered saline [Tris $(20 \mathrm{mM}), \mathrm{NaCl}(137 \mathrm{mM}), \mathrm{pH} 7.6]$ containing Tween-20 $(0.1 \% \mathrm{v} / \mathrm{v})(\mathrm{TBS}-$ Tween) for $1 \mathrm{~h}$ at room temperature. Primary antibodies used were rabbit anti-mouse TLR-4 (sc-30002; 1:200) and rabbit anti-human TLR-2 (sc-10739; 1:100) (both obtained from Santa Cruz, Heidelberg, Germany) diluted in blocking solution and incubated for $1 \mathrm{~h}$ at room temperature. After washing in TBS-Tween, incubation with secondary goat anti-rabbit IgG peroxidase conjugate (sc-2004, Santa Cruz) diluted 1:1000 in blocking solution was also for $1 \mathrm{~h}$ at room temperature. Immunoreactant bands were detected by enhanced chemiluminescence (Pierce, Northumberland, UK). Blots were then stripped and reprobed with rabbit anti-actin (Sigma A2066, $1: 2000)$ to check for equality of loading between lanes. 


\section{Caspase activity and superoxide production}

Superoxide production by intact cells was measured as superoxide dismutase inhibitable reduction of cytochrome C. ${ }^{21}$ Caspase 3-like activity on Transwell membranes, that had been rinsed in PBS, frozen in liquid nitrogen, and stored at $70^{\circ} \mathrm{C}$, was determined as described previously. ${ }^{25}$ Briefly, the release of fluorescent product from Ac-Asp-Glu-Val-Asp-7-amido-4-methylcoumarin was measured using a plate-reading spectrofluorimeter (Molecular Devices Ltd; Wokingham, UK). Alkaline phosphatase activity was extracted from frozen Transwell membranes, by thawing into extraction buffer ( $\mathrm{pH} 8.0)$ containing Tris (10 mM), $\mathrm{NaCl}(150 \mathrm{mM})$ and Triton X$100(0.5 \% \mathrm{v} / \mathrm{v})$. The extract $(50 \mu \mathrm{l})$ was transferred to $150 \mu \mathrm{l}$ of assay buffer $(\mathrm{pH} 9.2)$ comprising glycine (42 mM), $\mathrm{MgCl}_{2}(5 \mathrm{mM})$ and $p$-nitrophenylphosphate $(4.5 \mathrm{mM})$, and the mixture incubated for $1 \mathrm{~h}$ at $37^{\circ} \mathrm{C}$. The reaction was terminated by addition of $50 \mu \mathrm{l}$ of $\mathrm{NaOH}(1 \mathrm{M})$ and the absorbance read at $405 \mathrm{~nm}$.

\section{RESULTS}

\section{Colonic epithelial cells form a tight monolayer on Transwells}

The TEER increased markedly between three and six days of culture (Fig. 1A) but the subsequent increase was smaller (Fig. 1A). Although TEER varied somewhat between cultures, intra-culture variation was generally much less (Fig. 1B). There was a steep relationship between TEER and apparent permeability $\left(P_{\text {app }}\right)$. The mean $\mathrm{P}_{\text {app }}$ was similar to that found with a variety of colon cell lines derived from adenocarcinomas, which are know to form tight monolayers (Fig. 1C) ${ }^{24,26-30}$

Examination of vertical sections through Transwell preparations by light microscopy revealed a thin layer of cells (Fig. 2 A) with basally located nuclei (Fig. 2 
B, C). The dimensions of the nuclei were similar to that of surface epithelial cells in sections of colonic mucosa but their orientation was rotated through $90^{\circ}$ (compare Fig. $2 \mathrm{C}$ and D). Sections stained for mucus with periodic acid-Schiff reagent (Fig. 2 E) as did both colonic epithelial cells and goblet cells in sections of colonic mucosa (Fig. 2 F). The surface of the Transwell preparation stained for alkaline phosphatase (Fig. $2 \mathrm{G}$ ) as did surface regions of colonic mucosa (Fig. $2 \mathrm{H}$ ). The enzyme activity of alkaline phosphatase was $91 \pm 5 \mathrm{nmol} / \mathrm{h} / \mathrm{mg}$ protein. Superoxide production ( $83 \pm 21$ $\mathrm{nmol} / \mathrm{h} / \mathrm{mg}$ protein, $\mathrm{n}=4$ ), was much higher than in Caco-2 cells ${ }^{31}$ and similar to that of guinea pig $^{31}$ and human colonocytes ${ }^{32}$ in short-term culture. A low power fluorescent microscope image of cells fixed in situ on Transwells showed fairly evenly spaced nuclei and a 'lawn' of cytokeratin positive cells (Fig. 3 A, B), with more detail being shown by confocal microscopy (Fig. 3 C-E). To quantify the proportion of the various cell types, they were detached from the Transwell membrane and transferred to microscope slides by using a cytocentrifuge. A large proportion of cells were positive for the epithelial marker cytokeratin-18 $(94 \pm 2 \%, n=3$; Fig. $3 F, G)$ and for mucin as determined by periodic acid-Schiff staining ( $96 \pm 1 \%, n=3$, Fig. $3 \mathrm{H}, \mathrm{I})$. A small number of cells were positive for vimentin $(3.3 \pm 0.44 \% n=4$ Fig. $3 \mathrm{~J}, \mathrm{~K})$. These cells were also positive for $\alpha$-smooth muscle actin and were therefore probably myofibroblasts. ${ }^{33}$ Macrophages were undetectable.

Transmission electron microscopy showed flattened interleaved cell plates with an intact and continuous apical surface but with extensive basolateral spaces. Nuclei were mainly basal (Fig. 4 A, B). Desmosomes and tight junctions were visible (Fig. 4 C). The flattened nature of the primary culture may result from the lack of any constraint to lateral spreading and to rapid inhibition of cell division on contact. Caco-2 cells appear more columnar in culture and this may result from the much 
greater nuclear density that can be obtained with these cells than with the primary culture (Fig. $4 \mathrm{D}$ and E).

The Transwell preparation expressed both TLR-4 and TLR-2 after $8 \mathrm{~d}$ of culture and incubation for $5 \mathrm{~h}$ in the absence (Fig. 5 left-hand two lanes) or presence (Fig. 5 right-hand two lanes) of basal LPS $\left(10^{-7} \mathrm{~g} / \mathrm{ml}\right)$. The amount of these proteins appeared unaffected by the presence of LPS.

Basal but not apical LPS increased tight junction permeability and apoptosis During 4-5 $\mathrm{h}$ after exposure to basally applied E. coli LPS, transfer of mannitol from the apical to the basal compartment was increased (Fig. 6A). The dose response curve for this effect was "bell-shaped" with LPS showing a maximal action at $10^{-7}$ $\mathrm{g} / \mathrm{ml}$. Basal LPS produced a decrease in TEER, the magnitude of which correlated with the increase in permeability to mannitol (Fig. 6B). The effect of $10^{-7} \mathrm{~g} / \mathrm{ml}$ LPS on transfer of mannitol increased with time (Fig. 6C). The presence of LPS in the apical compartment affected neither permeability to mannitol nor TEER (Fig. 6 A-C). Basal application of LPS $\left(10^{-7} \mathrm{~g} / \mathrm{ml}\right)$ increased apoptotic activity as evidenced by an increase in caspase 3-like activity, in contrast to apical application (Fig. 6 D), and in the proportion of cells showing nuclear condensation and fragmentation (Fig. 6 E-F). Overall viability at the end of a $5 \mathrm{~h}$ experiment was assessed by the proportion of bisbenzimide stained nuclei that did not stain with propidium iodide and was $>99 \%$ in both the absence and presence of basal LPS $\left(10^{-7} \mathrm{~g} / \mathrm{ml}\right)$.

\section{The effect of LPS on permeability to mannitol and FD 10 was proportionate}

Treatment of T84 cells with cytokines caused a much bigger increase in permeability to FD10, than to mannitol. ${ }^{34}$ Basally applied E. coli LPS $\left(10^{-7} \mathrm{~g} / \mathrm{ml}\right)$ increased 
permeability to mannitol, which has a hydrodynamic radius of $4.1 \AA^{35}$ and to FD10 with a hydrodynamic radius of $23 \AA$ (Fig. 7). ${ }^{36}$ However, the magnitude of the change in permeability to these probes induced by LPS was very similar (Fig. 7 insert).

H. pylori LPS increases paracellular permeability when applied to either the apical or basal sides of gastric cells but only affects colon cells from the basal aspect In order to establish whether the lack of response to apically applied LPS was a particular feature of colon cells, we undertook a comparison with gastric cells. We used a previously established preparation of gastric surface epithelial cells ${ }^{21}$, and LPS from the gastric pathogen $H$. pylori. The bioactivities of LPS from $H$. pylori are generally less potent than that from E. coli, ${ }^{23,37,38}$ but at concentrations of $10^{-6} \mathrm{~g} / \mathrm{ml}$ and above, it increased permeability to mannitol and decreased TEER when applied either to the apical or the basal aspect of gastric epithelial cells (Fig. 8). In contrast, H. pylori LPS only affected transfer of mannitol and TEER when applied to the basal aspect of colon cells (Fig. 8).

Inhibition of caspase activation reduces the effect of LPS on paracellular permeability and TEER

As shown in Fig. 9, when the pan-caspase inhibitor Z-VAD-FMK was present in the basal compartment of the Transwell, $5 \mathrm{~h}$ incubation with E. coli LPS did not increase caspase activity, in contrast to when Z-VAD-FMK was absent. Furthermore, the effects of LPS on permeability to mannitol and TEER were significantly reduced $(P<0.05$ and $P<0.01$, respectively $)$. 
The synthetic TLR-2 agonist, $\mathrm{Pam}_{3} \mathrm{CSK}_{4}$ does not mimic the effects of LPS but rather inhibits them

When applied to either the apical or basal aspect of the preparation $\mathrm{Pam}_{3} \mathrm{CSK}_{4}$ did not significantly affect permeability to mannitol, TEER or caspase activity (Fig. 10, open bars). Nevertheless, when $\mathrm{Pam}_{3} \mathrm{CSK}_{4}$ was present in the basal compartment, $10^{-7} \mathrm{~g} / \mathrm{ml}$ basal E. coli LPS did not significantly increase permeability to mannitol or caspase activity, or significantly decrease TEER. With $\mathrm{Pam}_{3} \mathrm{CSK}_{4}$ in the apical compartment there was still a significant effect of basally applied LPS on TEER and caspase activity (Fig. $10 \mathrm{~B}-\mathrm{C}$ ) but not on mannitol transfer. However, in the presence of apical $\mathrm{Pam}_{3} \mathrm{CSK}_{4}$ the effect of LPS on TEER was significantly reduced from a decrease of $55 \pm 8 \%$ to $39 \pm 6 \%$ ( $n=4, \%$ calculated with respect to appropriate control, $\mathrm{P}<0.05$ by paired t-test). In summary, basally applied $\mathrm{Pam}_{3} \mathrm{CSK}_{4}$ completely abolished all effects of LPS on paracellular permeability, and apically applied $\mathrm{Pam}_{3} \mathrm{CSK}_{4}$ effected a partial inhibition of LPS action.

\section{DISCUSSION}

The primary culture procedure used in this study gave rise to a confluent monolayer the tight junctions of which exhibit permeability to mannitol similar to that of adenocarcinoma cell lines (Fig. 1C). The initial TEER is somewhat higher than the $3300 \Omega . \mathrm{cm}^{2}$ of T84 cells, ${ }^{39}$ and considerably higher than that of Caco-2 cells. ${ }^{24,29}$ The other only apparent report of a primary colon culture, with separated apical and basal compartments, used weanling rats and had a much lower TEER, but was not characterized as to cell type ${ }^{40}$ The key features of this present procedure are: (i) the use of guinea pig colonic mucosa which disaggregates rapidly compared to mouse 
mucosa, (ii) usage of pronase to remove mucus during the disaggregation of tissue, ${ }^{41}$ and (iii) utilization of Transwells which promote long-term cell survival much better than a plastic substratum. Surface, but not crypt, guinea pig colonic epithelial cells express Nox 1, which enables them to produce superoxide. ${ }^{31}$ Alkaline phosphatase activity and apical membrane staining are features of colonic epithelial cells. ${ }^{42}$ Colonic epithelial cells contain MUC4, ${ }^{43}$ and are periodic acid-Schiff positive. ${ }^{31}$ The production of superoxide, the presence of alkaline phosphatase and the high proportion of cells staining positively with periodic acid-Schiff reagent and for cytokeratin-18, indicate that the present preparations contain primarily colonic epithelial cells, resembling surface rather than crypt cells. Cells were rather flattened, about half the height, of guinea-pig colonocytes in intact mucosa. ${ }^{44}$ Such flattening is found in primary cultures of jejunal ${ }^{45}$ and tracheal cells, ${ }^{46}$ and probably reflects the tendency of epithelial cells to spread as in wound healing until they reach contact when there is immediate inhibition of cell division. Attempts to increase the cell density by plating increased numbers of crypt fragments did not enhance monolayer formation possibly because fragments attached to each other rather than to the Transwell membrane. In a three dimensional system in vivo there is considerable lateral pressure which may induce a more columnar appearance by the cells.

The bell-shaped dose response curves of E. coli LPS are characteristic of many actions of LPS mediated via TLR-4, e.g. in resected human ileal mucosa ${ }^{47}$ and in the murine intestinal epithelial cell line $\mathrm{m}-\mathrm{IC}_{\mathrm{cl} 2 .}{ }^{16}$ Furthermore, the low concentration at which LPS is effective implies a specific effect via TLR-4, and contrasts with the effect of high concentrations of apically applied LPS on Caco-2 cells which appear to be mediated by CD14 and not TLR-4. ${ }^{48}$ The comparison 
between the effects of highly purified LPS from $H$. pylori on stomach and colon cells, both grown on Transwells, shows that the effect of LPS on colon cells is specific to tissue, but not to the bacterial source of LPS. Furthermore, the results fit with the expectations derived from current knowledge of the relationship between the tissues and microorganism expressing the LPS. Thus, $H$. pylori is a gastric pathogen and an increase in permeability of tight junctions to allow delivery of antibodies to the bacterium would seem an appropriate physiological response. In contrast, the colonic epithelium has to tolerate a high luminal LPS load from the commensal enteric flora that are present and a lack of response to apical LPS would therefore seem appropriate. The significance of the effect of basal LPS on gut permeability needs further exploration but could clearly be of importance in exacerbating a defective permeability barrier.

The action of LPS on paracellular permeability is probably not mediated indirectly by cytokines such as TNF- $\alpha$ and interferon-gamma (IFN- $\gamma$ ). This is because, firstly, the effect of LPS observed here is evident after $2 \mathrm{~h}$ of exposure, whereas $24 \mathrm{~h}$ of exposure to such cytokines is required for an effect on paracellular permeability in intestinal (Caco-2) cells to be evident. ${ }^{8}$ Secondly, in contrast to the effect of LPS found in the present study, cytokines act preferentially on a subset of pores to increase the permeability of higher molecular mass probes (FD 10) to a greater extent than mannitol. ${ }^{34}$ Thirdly, the effect of cytokines can occur in the absence of the activation of caspases, ${ }^{49}$ in contrast to the caspase-dependent phenomenon observed here. The dependence of the LPS-mediated increase in paracellular permeability on caspase activation may reflect increased leakage through apoptotic cells, ${ }^{39,50}$ or caspase-mediated cleavage and activation of Rhoassociated protein kinase 1 (ROCK-1) $)^{51}$ which can enhance paracellular 
permeability. ${ }^{52}$ Such issues are the focus of our future studies. Overall, the findings suggest that the current paradigm that the effects of PAMPs on gut permeability are primarily mediated by the action of cytokines released from leukocytes ${ }^{6-8}$ may have to be modified to include direct effects on epithelial cells of one such pattern molecule, i.e. LPS.

Synthetic $\mathrm{Pam}_{3} \mathrm{CSK}_{4}$ is a specific ligand for TLR-2. ${ }^{53}$ The $\mathrm{Pam}_{3} \mathrm{CSK}_{4}$ ligand has been reported to increase TEER in Caco- 2 cells ${ }^{16}$, but no significant effect of this agent was found in the present preparation of colon cells. This disparity may reflect the transient effect of $\mathrm{Pam}_{3} \mathrm{CSK}_{4}$ in Caco-2 cells or differences between the preparations. Nevertheless, beneficial effects of $\mathrm{Pam}_{3} \mathrm{CSK}_{4}$-induced responses on the permeability barrier were observed in this study, namely the prevention of the deleterious effect of $E$. coli LPS. The prevention of LPS-induced apoptosis by $\mathrm{Pam}_{3} \mathrm{CSK}_{4}$ is echoed by its inhibition of spontaneous apoptosis in sheets of mouse small intestine in primary culture ${ }^{54}$. Finally, our finding that $\mathrm{Pam}_{3} \mathrm{CSK}_{4}$ delivered from the apical side was active in countering the effect of basal LPS is consistent with the use of orally delivered $\mathrm{Pam}_{3} \mathrm{CSK}_{4}$ to ameliorate the effect of dextran sodium sulphate-induced colitis in mice. ${ }^{54}$ There are, thus, parallels between the present work and that of others ${ }^{16,54}$ which suggest a beneficial effect of $\mathrm{Pam}_{3} \mathrm{CSK}_{4}$ on the permeability barrier. Furthermore, the work raises issues related to the cross-talk between TLR-2 and TLR-4 in the colon in response to PAMPs.

In conclusion, LPS increased paracellular permeability of colonic epithelial cells only when added from the basal side by a mechanism which involved caspase activation. Perturbation of the gut barrier, which allows access of LPS to the base of colonic epithelial cells, could therefore result in a further exacerbation in paracellular permeability. The lack of effect of apically applied LPS on paracellular permeability 
may contribute to the ability of the colon to exist in harmony with the enteric flora. Of note, $\mathrm{Pam}_{3} \mathrm{CSK}_{4}$, an activator of TLR-2-mediated responses, prevented all effects induced by basally applied LPS, which suggests a possible protective effect of this agent in the colon. 


\section{ACKNOWLEDGEMENTS}

We would like to thank Chris Bache and Jiteen Kansara for technical assistance, Dr

Steve Smith for assistance with confocal microscopy, and Carol Evered and Jane Green (University of Warwick) for electron microscopy. 


\section{REFERENCES}

1. Hollander D. Crohn's-Disease - a Permeability Disorder of the Tight Junction. Gut 1988;29:1621-1624.

2. Katz KD, Hollander D, Vadheim CM, et al. Intestinal Permeability in Patients with Crohn's-Disease and Their Healthy Relatives. Gastroenterology 1989;97:927-931.

3. May GR, Sutherland LR, Meddings JB. Is Small-Intestinal Permeability Really Increased in Relatives of Patients with Crohn's-Disease. Gastroenterology 1993;104:1627-1632.

4. Schmitz $\mathrm{H}$, Barmeyer $\mathrm{C}$, Fromm $\mathrm{M}$, et al. Altered tight junction structure contributes to the impaired epithelial barrier function in ulcerative colitis. Gastroenterology 1999;116:301-309.

5. Wyatt J, Vogelsang H, Hubl W, Waldhoer T, Lochs H. Intestinal Permeability and the Prediction of Relapse in Crohn's-Disease. Lancet 1993;341:14371439.

6. Clayburgh DR, Shen L, Turner JR. A porous defense: the leaky epithelial barrier in intestinal disease. Lab Invest 2004;84:282-291.

7. Heller F, Florian P, Bojarski C, et al. Interleukin-13 is the key effector Th2 cytokine in ulcerative colitis that affects epithelial tight junctions, apoptosis, and cell restitution. Gastroenterology 2005;129:550-564.

8. Wang FJ, Graham WV, Wang YM, Witkowski ED, Schwarz BT, Turner JR. Interferon-gamma and tumor necrosis factor-alpha synergize to induce intestinal epithelial barrier dysfunction by up-regulating myosin light chain kinase expression. Am J Pathol 2005;166:409-419.

9. Abreu MT, Arnold ET, Thomas LS, et al. TLR4 and MD-2 expression is regulated by immune-mediated signals in human intestinal epithelial cells. $J$ Biol Chem 2002;277:20431-20437.

10. Otte JM, Cario E, Podolsky DK. Mechanisms of cross hyporesponsiveness to toll-like receptor bacterial ligands in intestinal epithelial cells. Gastroenterology 2004;126:1054-1070.

11. Singh JCI, Cruickshank SM, Newton DJ, et al. Toll-like receptor-mediated responses of primary intestinal epithelial cells during the development of colitis. American Journal of Physiology-Gastrointestinal and Liver Physiology 2005;288:G514-G524.

12. Cario E, Podolsky DK. Differential alteration in intestinal epithelial cell expression of Toll-like receptor 3 (TLR3) and TLR4 in inflammatory bowel disease. Infect Immun 2000;68:7010-7017.

13. Eutamene $H$, Theodorou V, Schmidlin F, et al. LPS-induced lung inflammation is linked to increased epithelial permeability: role of MLCK. Eur Respir $J$ 2005;25:789-796.

14. Yi X, Wang Y, Yu FSX. Corneal epithelial tight junctions and their response to lipopolysaccharide challenge. Invest Ophthalmol Vis Sci 2000;41:4093-4100.

15. Sheth P, Delos Santos N, Seth A, LaRusso NF, Rao RK. Lipopolysaccharide disrupts tight junctions in cholangiocyte monolayers by a c-Src-, TLR4-, and LBP-dependent mechanism. American Journal of Physiology-Gastrointestinal and Liver Physiology 2007;293:G308-G318. 
16. Hornef MW, Frisan T, Vandewalle A, Normark S, Richter-Dahlfors A. Toll-like receptor 4 resides in the Golgi apparatus and colocalizes with internalized lipopolysaccharide in intestinal epithelial cells. J Exp Med 2002;195:559-570.

17. Furrie E, Macfarlane S, Thomson G, Macfarlane GT. Toll-like receptors-2,-3 and-4 expression patterns on human colon and their regulation by mucosalassociated bacteria. Immunology 2005;115:565-574.

18. Cario E, Podolsky DK. Intestinal epithelial TOLLerance versus inTOLLerance of commensals. Mol Immunol 2005;42:887-893.

19. Cario E, Gerken G, Podolsky DK. Toll-like receptor 2 enhances ZO-1associated intestinal epithelial barrier integrity via protein kinase $\mathrm{C}$. Gastroenterology 2004;127:224-238.

20. Suzuki M, Hisamatsu T, Podolsky DK. Gamma interferon augments the intracellular pathway for lipopolysaccharide (LPS) recognition in human intestinal epithelial cells through coordinated up-regulation of LPS uptake and expression of the intracellular toll-like receptor 4-MD-2 complex. Infect Immun 2003;71:3503-3511.

21. Kavvada KM, Murray JG, Moore VA, Coombes AGA, Hanson PJ. A collagen IV matrix is required for guinea pig gastric epithelial cell monolayers to provide an optimal model of the stomach surface for biopharmaceutical screening. Journal of Biomolecular Screening 2005;10:495-507.

22. Kavvada KM, Murray JG, Moore VA, Coombes AGA, Hanson PJ. High permeability of the anionic form restricts accumulation of indomethacin by cultured gastric surface epithelial cells exposed to low apical $\mathrm{pH}$. Eur $J$ Pharmacol 2006;549:41-49.

23. Durkin E, Moran AP, Hanson PJ. Apoptosis induction in gastric mucous cells in vitro: lesser potency of Helicobacter pylori than Escherichia coli lipopolysaccharide, but positive interaction with ibuprofen. Journal of Endotoxin Research 2006;12:47-56.

24. Tavelin S, Milovic V, Ocklind G, Olsson S, Artursson P. A conditionally immortalized epithelial cell line for studies of intestinal drug transport. $J$ Pharmacol Exp Ther 1999;290:1212-1221.

25. Ashton M, Hanson PJ. Disparate effects of non-steroidal anti-inflammatory drugs on apoptosis in guinea-pig gastric mucous cells: inhibition of basal apoptosis by diclofenac. Br J Pharmacol 2002;135:407-416.

26. Wikman A, Karlsson J, Carlstedt I, Artursson P. A Drug Absorption-Model Based on the Mucus Layer Producing Human Intestinal Goblet Cell-Line Ht29H. Pharm Res 1993;10:843-852.

27. Collett A, Sims E, Walker D, et al. Comparison of HT29-18-C-1 and Caco-2 cell lines as models for studying intestinal paracellular drug absorption. Pharm Res 1996;13:216-221.

28. Blais A, Aymard P, Lacour B. Paracellular calcium transport across Caco-2 and HT29 cell monolayers. Pflugers Archiv-European Journal of Physiology 1997;434:300-305.

29. Rao RK, Baker RD, Baker SS, Gupta A, Holycross M. Oxidant-induced disruption of intestinal epithelial barrier function: role of protein tyrosine phosphorylation. American Journal of Physiology-Gastrointestinal and Liver Physiology 1997;273:G812-G823.

30. Yoo J, Nichols A, Song JC, et al. Bryostatin-1 attenuates TNF-induced epithelial barrier dysfunction: role of novel PKC isozymes. American Journal of Physiology-Gastrointestinal and Liver Physiology 2003;284:G703-G712. 
31. Kawahara T, Kuwano Y, Teshima-Kondo S, et al. Role of nicotinamide adenine dinucleotide phosphate oxidase 1 in oxidative burst response to tolllike receptor 5 signaling in large intestinal epithelial cells. J Immunol 2004;172:3051-3058.

32. Perner A, Andresen L, Pedersen G, Rask-Madsen J. Superoxide production and expression of $\mathrm{NAD}(\mathrm{P}) \mathrm{H}$ oxidases by transformed and primary human colonic epithelial cells. Gut 2003;52:231-236.

33. Beltinger J, McKaig BC, Makh S, Stack WA, Hawkey CJ, Mahida YR. Human colonic subepithelial myofibroblasts modulate transepithelial resistance and secretory response. American Journal of Physiology-Cell Physiology 1999;277:C271-C279.

34. Watson CJ, Hoare CJ, Garrod DR, Carlson GL, Warhurst G. Interferongamma selectively increases epithelial permeability to large molecules by activating different populations of paracellular pores. J Cell Sci 2005;118:5221-5230.

35. Kaskel FJ, Kumar AM, Lockhart EA, Evan A, Spitzer A. Factors Affecting Proximal Tubular Reabsorption During Development. Am J Physiol 1987;252:F188-F197.

36. Sanders SE, Madara JL, McGuirk DK, Gelman DS, Colgan SP. Assessment of inflammatory events in epithelial permeability: A rapid screening method using fluorescein dextrans. Epithelial Cell Biol 1995;4:25-34.

37. Muotiala A, Helander IM, Pyhala L, Kosunen TU, Moran AP. Low BiologicalActivity of Helicobacter-Pylori Lipopolysaccharide. Infect Immun 1992;60:1714-1716.

38. Moran A. Lipopolysaccahride in bacterial chronic infection: insights from Helicobacter pylori lipopolysaccharide and lipid A. Int J Med Microbiol 2007;297:307-319.

39. Abreu MT, Palladino AA, Arnold ET, Kwon RS, McRoberts JA. Modulation of barrier function during fas-mediated apoptosis in human intestinal epithelial cells. Gastroenterology 2000;119:1524-1536.

40. Horster M, Fabritius J, Buttner M, Maul R, Weckwerth P. Colonic-CryptDerived Epithelia Express Induced Ion-Transport Differentiation in MonolayerCultures on Permeable Matrix Substrata. Pflugers Archiv-European Journal of Physiology 1994;426:110-120.

41. Mantle M, Forstner GG, Forstner JF. Antigenic and Structural Features of Goblet-Cell Mucin of Human Small-Intestine. Biochem J 1984;217:159-167.

42. Dahan S, Roda G, Pinn D, et al. Epithelial: Lamina propria lymphocyte interactions promote epithelial cell differentiation. Gastroenterology 2008;134:192-203.

43. Winterford CM, Walsh MD, Leggett BA, Jass JR. Ultrastructural localization of epithelial mucin core proteins in colorectal tissues. J Histochem Cytochem 1999;47:1063-1074.

44. Hass R, Busche R, Luciano L, Reale E, vonEngelhardt W. Lack of butyrate is associated with induction of Bax and subsequent apoptosis in the proximal colon of guinea pig. Gastroenterology 1997;112:875-881.

45. Weng XH, Beyenbach KW, Quaroni A. Cultured monolayers of the dog jejunum with the structural and functional properties resembling the normal epithelium. American Journal of Physiology-Gastrointestinal and Liver Physiology 2005;288:G705-G717. 
46. Davidson DJ, Kilanowski FM, Randell SH, Sheppard DN, Dorin JR. A primary culture model of differentiated murine tracheal epithelium. American Journal of Physiology-Lung Cellular and Molecular Physiology 2000;279:L766-L778.

47. Masumoto J, Kobayashi H, Nakamura T, et al. Regulation of the ASC expression in response to LPS stimulation is related to IL-8 secretion in the human intestinal mucosa. Biochem Biophys Res Commun 2006;346:968-973.

48. Yu LCH, Turner JR, Buret AG. LPS/CD14 activation triggers SGLT-1-mediated glucose uptake and cell rescue in intestinal epithelial cells via early apoptotic signals upstream of caspase-3. Exp Cell Res 2006;312:3276-3286.

49. Bruewer M, Luegering A, Kucharzik T, et al. Proinflammatory cytokines disrupt epithelial barrier function by apoptosis-independent mechanisms. J Immunol 2003;171:6164-6172.

50. Gitter AH, Bendfeldt K, Schulzke JD, Fromm M. Leaks in the epithelial barrier caused by spontaneous and TNF-alpha-induced single-cell apoptosis. FASEB J 2000;14:1749-1753.

51. Chang J, Xie M, Shah VR, et al. Activation of Rho-associated coiled-coil protein kinase 1 (ROCK-1) by caspase-3 cleavage plays an essential role in cardiac myocyte apoptosis. Proc Natl Acad Sci U S A 2006;103:14495-14500.

52. Hirase T, Kawashima S, Wong EYM, et al. Regulation of tight junction permeability and occludin phosphorylation by RhoA-p160ROCK-dependent and -independent mechanisms. J Biol Chem 2001;276:10423-10431.

53. Ozinsky A, Underhill DM, Fontenot JD, et al. The repertoire for pattern recognition of pathogens by the innate immune system is defined by cooperation between Toll-like receptors. Proc Natl Acad Sci U S A 2000;97:13766-13771.

54. Cario E, Gerken G, Podolsky DK. Toll-like receptor 2 controls mucosal inflammation by regulating epithelial barrier function. Gastroenterology 2007;132:1359-1374. 


\section{Legends to Figures}

Fig. 1. Transepithelial electrical resistance (TEER) and paracellular permeability of colonic cells. (A) Increase in TEER with culture time. Data are means \pm SEM from 10 experiments. (B) Initial TEER and its relationship to basal permeability to mannitol for eight-day cultures. Data points are means \pm SEM for 14 plates from 7 experiments with 12 wells on each plate. (C) Comparison between apparent permeability to mannitol from different preparations of colon cells. Superscripts after the cell type indicate the source of the information (reference list).

Fig. 2. Light microscopy pictures of cryostat sections $(10 \mu \mathrm{m})$ through Transwell membranes (A-C, E, G) and colonic mucosa (D, F, H, apical surfaces to the left). (A) Phase contrast view of unstained tissue. (B) The same section as in (A) under UV illumination showing nuclei stained with 4', 6-diamidino-2-phenylindole dihydrochloride (DAPI) (the position of the membrane is shown by the horizontal white lines). Sections stained with haematoxylin and eosin $(C)$, with haematoxylin (D), with periodic acid-Schiff reagent $(E)$ and $(F)$ (goblet cells indicated by arrows in F), and for alkaline phosphatase (arrows) $(G)$ and $(H)$. (A-E) and $(G)$ are all at the same magnification and which can be judged from the thickness of the Transwell membrane $(10 \mu \mathrm{m}) .(\mathrm{F})$ and $(\mathrm{H})$ are shown at $25 \%$ relative to the other pictures to enable the whole depth of the mucosa to be visible.

Fig. 3. Examination of cells grown for 8 days on Transwells and fixed in situ (A-E) or detached, and transferred to microscope slides by use of a cytocentrifuge (F-K). (A) Low power image showing nuclei stained with DAPI. (B) The same cells as in (A) 
showing extensive staining for cytokeratin-18. (C) Nuclei and (D) and (E) x, y confocal images, respectively, in and above the plane of the nuclei showing the presence of cytokeratin-18. (F) Nuclei and (G) cytokeratin-18-positive cells on cytocentrifuge preparations. $(\mathrm{H})$ Nuclei and (I) corresponding periodic acid-Schiff stained cells. (J) Nuclei and (K) corresponding vimentin-positive cell (arrow).

Fig. 4. Transmission electron microscopy of vertical sections through the Transwell preparation. (A) Image showing a cross section of the monolayer resting on the filter. (B) Higher magnification image showing a basally located nucleus (arrow) and a cluster of granules $\left(^{*}\right)$. (C) Microvilli, desmosomes (twin white arrows) and apical junction complexes (single black arrow) were visible. (E) and (F) Nuclear density achieved, respectively, with the present primary culture and with Caco-2 cells.

Fig. 5. Immunoblots for TLR-4 and TLR-2 with corresponding actin loading controls for cells incubated for $5 \mathrm{~h}$ in the absence (control) or presence of LPS $\left(10^{-7} \mathrm{~g} / \mathrm{ml}\right)$.

Fig. 6. (A) Effect of the concentration of apical LPS (open bars) and basal LPS (filled bars) from $E$. coli on permeability to mannitol, and (B) on transepithelial electrical resistance (TEER). Permeability was measured over a $1 \mathrm{~h}$ period starting $4 \mathrm{~h}$ after exposure to LPS was initiated. The TEER was measured $5 \mathrm{~h}$ after exposure to LPS was started. (C) The change in the rate of mannitol transfer from apical to basal with time of exposure to LPS $\left(10^{-7} \mathrm{~g} / \mathrm{ml}\right)$. (D) Effect of the concentration of LPS on caspase 3-like activity measured $5 \mathrm{~h}$ after the start of exposure to LPS. In (A-D) data are means \pm SEM from four experiments; ${ }^{*} \mathrm{P}<0.05$, ${ }^{* *} \mathrm{P}<0.01$ after analysis of variance followed by Dunnett's test for comparison with results in the absence of LPS 


\begin{abstract}
$(A, B, D)$ or with the data for 0-1 h (C). (E) Nuclei on Transwells stained with 4', 6diamidino-2-phenylindole dihydrochloride (DAPI) after $5 \mathrm{~h}$ incubation without or with LPS $\left(10^{-7} \mathrm{~g} / \mathrm{ml}\right)$ in the basal compartment. Arrows point to apoptotic nuclei exhibiting features of condensation and fragmentation. (F) The proportion of apoptotic cells on Transwells after incubation for $5 \mathrm{~h}$ in the absence or presence of basal LPS $\left(10^{-7}\right.$ $\mathrm{g} / \mathrm{ml}$ ). Data are means \pm SEM of six Transwells from three experiments ${ }^{* \star} \mathrm{P}<0.01$ by t-test.
\end{abstract}

Fig. 7. Effect of basally applied E. coli LPS $\left(10^{-7} \mathrm{~g} / \mathrm{ml}\right)$ (filled bars) compared to controls (open bars) on the apical to basal transfer of fluorescein isothiocyanatelabelled dextran $10 \mathrm{kDa}$ (FD10) and mannitol. Results, for the period 4-5 h after exposure to LPS was initiated, are means \pm SEM from four experiments; ${ }^{*} \mathrm{P}<0.05$ and ${ }^{* *} \mathrm{P}<0.01$ for comparison with control by paired t-test. The insert shows a lack of difference between FD10 and mannitol in the magnitude of the effect of LPS on their transfer.

Fig. 8. Comparison between gastric and colonic epithelial cells of the effect of incubation with apically applied (open bars) and basally applied (filled bars) LPS from H. pylori. (A) Apical to basal transfer of mannitol and (B) the transepithelial electrical resistance (TEER). Data were collected between 2-4 h after exposure of gastric cells to LPS, and from 4-5 $\mathrm{h}$ after exposure of colonic cells to LPS. The data are means \pm SEM from three experiments for gastric cells and four experiments with colon cells. ${ }^{*} \mathrm{P}<0.05$ and ${ }^{*} \mathrm{P}<0.01$ for comparison with no LPS by analysis of variance and Dunnett's test. 
Fig. 9. Action of the pan-caspase inhibitor Z-VAD-FMK $(50 \mu \mathrm{M})$ in the basal compartment (shaded bars) on the actions of basal E. coli LPS $\left(10^{-7} \mathrm{~g} / \mathrm{ml}\right)$. Mannitol transfer was measured between 4-5 h after exposure to LPS was initiated and transepithelial electrical resistance (TEER) and caspase 3-like activity after $5 \mathrm{~h}$. Results are means \pm SEM from four experiments and were obtained by calculating the effect of LPS in the presence and absence of Z-VAD-FMK. This inhibitor had no effect on mannitol transfer, TEER or caspase 3-like activity in the absence of LPS. ${ }^{\star} \mathrm{P}<0.05,{ }^{* \star} \mathrm{P}<0.01,{ }^{* \star} \mathrm{P}<0.001$ for comparisons between the effect of LPS in the presence and absence of Z-VAD-FMK by a paired t-test.

Fig. 10. Effect of the TLR-2 agonist Pam ${ }_{3} \mathrm{CSK}_{4}(20 \mu \mathrm{g} / \mathrm{ml})$. (A) Permeability to mannitol, (B) transepithelial electrical resistance (TEER) and (C) caspase 3-like activity in the absence (open bars) and presence (filled bars) of basal E. coli LPS (10$\left.{ }^{7} \mathrm{~g} / \mathrm{ml}\right)$. Results are means \pm SEM of four experiments. ${ }^{*} P<0.05,{ }^{* \star} P<0.01$ for effect of LPS in the absence of $\mathrm{Pam}_{3} \mathrm{CSK}_{4}$, or its presence in basal, or in apical compartments, by analysis of variance and a Newman-Keuls test. The same test showed no significant effect of $\mathrm{Pam}_{3} \mathrm{CSK}_{4}$ on mannitol transfer, TEER or caspase 3like activity with respect to controls (no addition). 


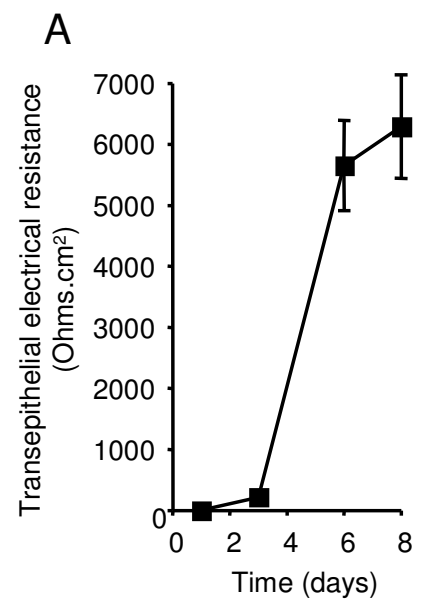

C

HT29-Cl.19A (secretory cell clone)29 HT29-H (goblet cell clone) ${ }^{27}$ HT29-18-C1 clone 28 Caco-2 cell line ${ }^{30}$ T84 cell line ${ }^{30}$ Caco-2 cell line 24 Colon primary, present work T84 cell line ${ }^{3}$
B

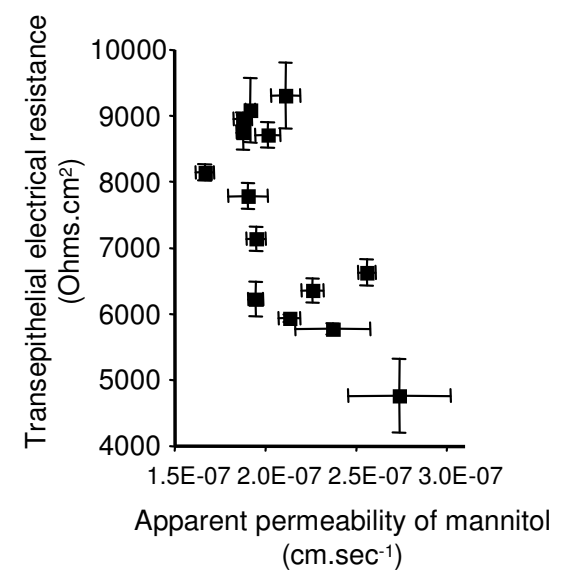



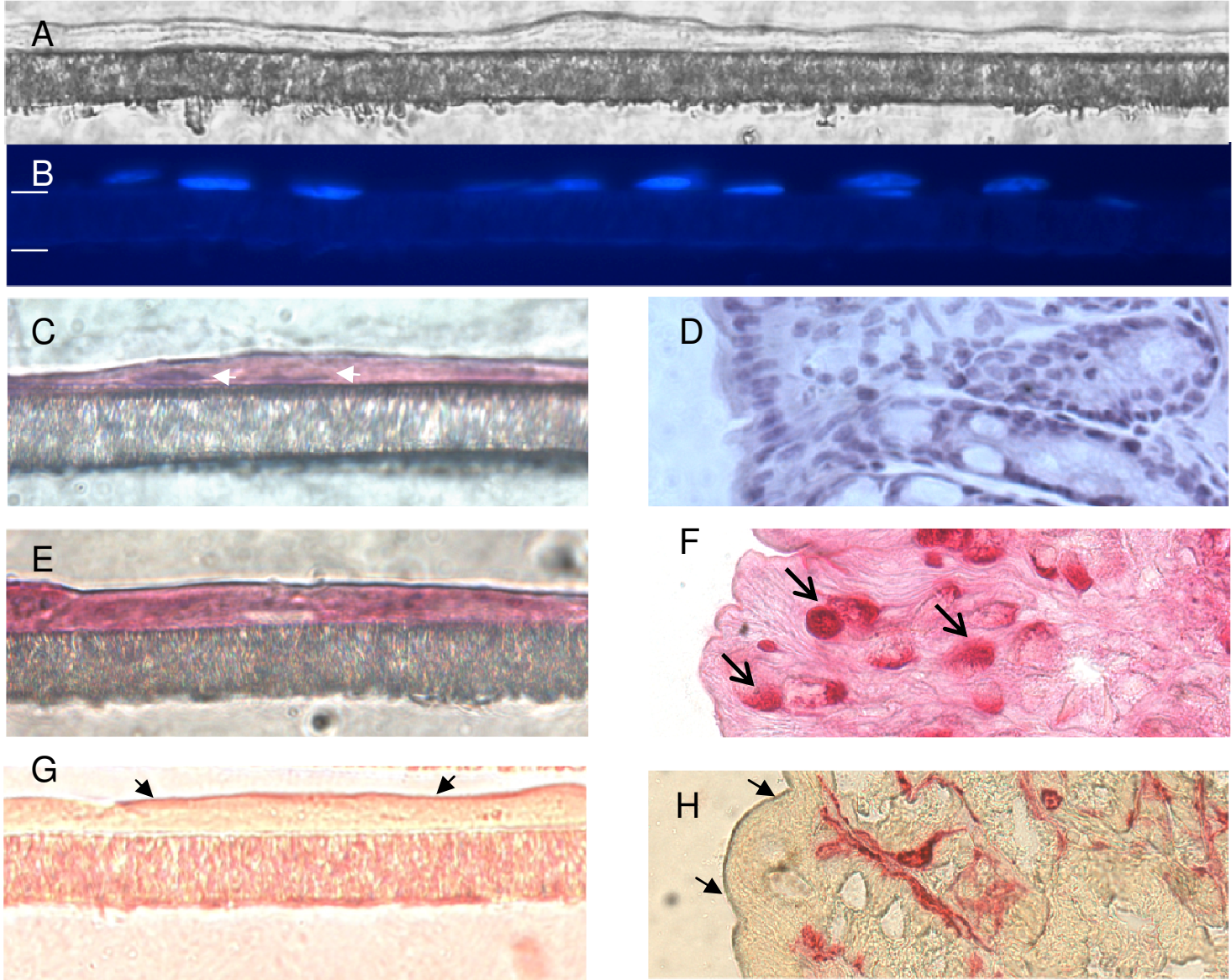

Fig. 2 

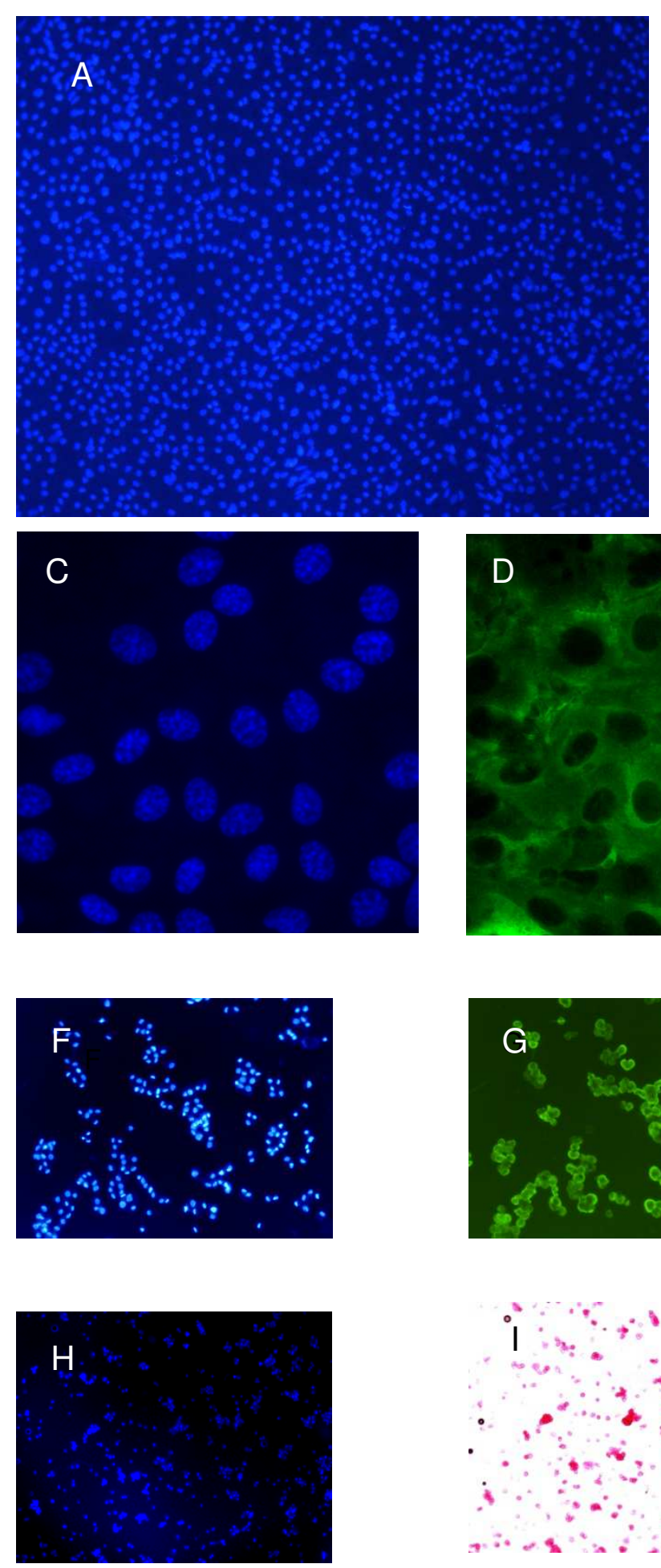
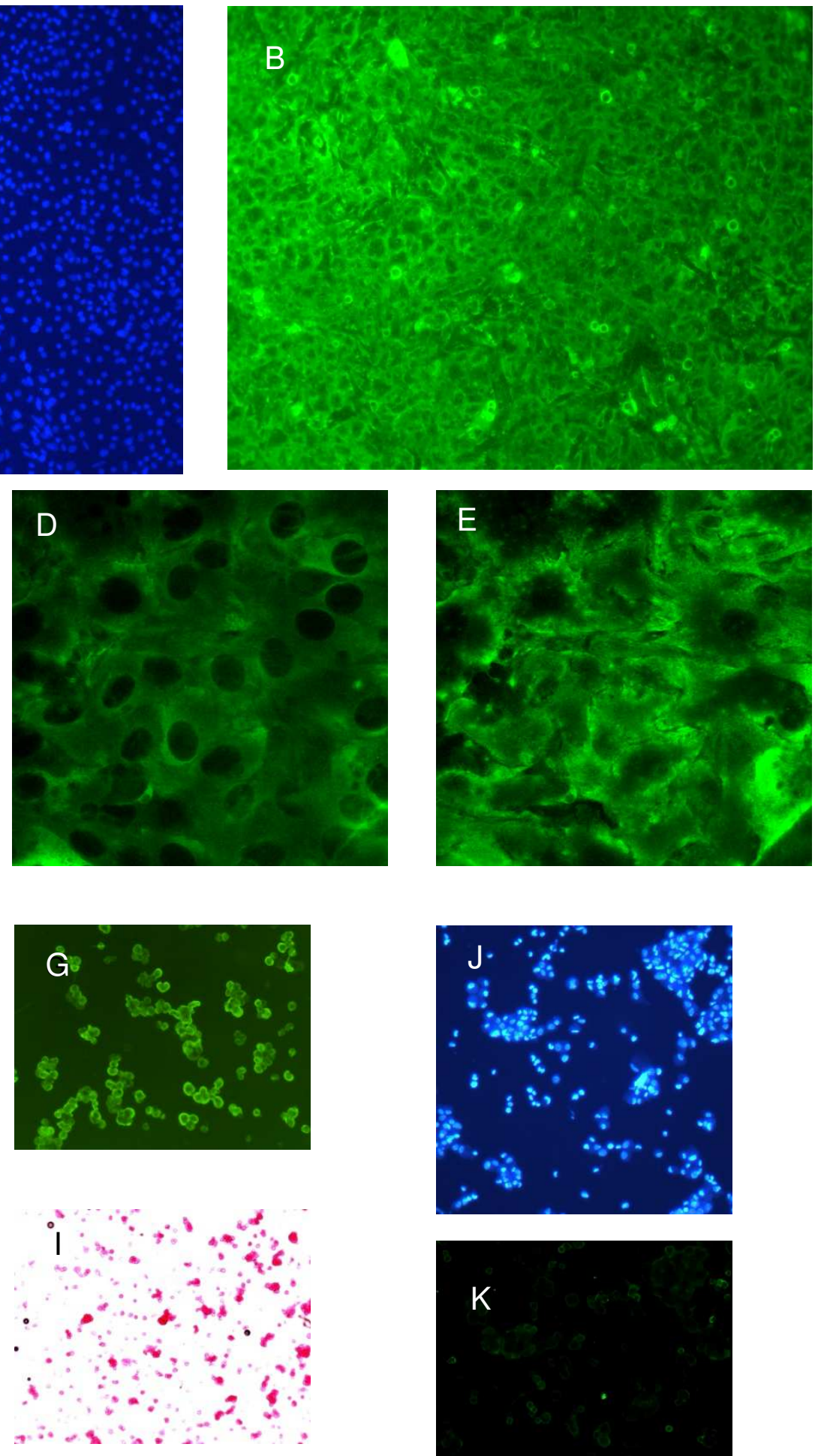

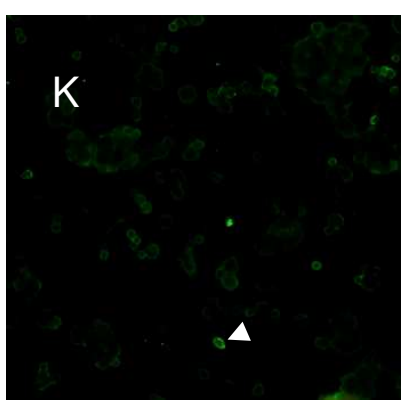

Fig. 3

http://mc.manuscriptcentral.com/INI 

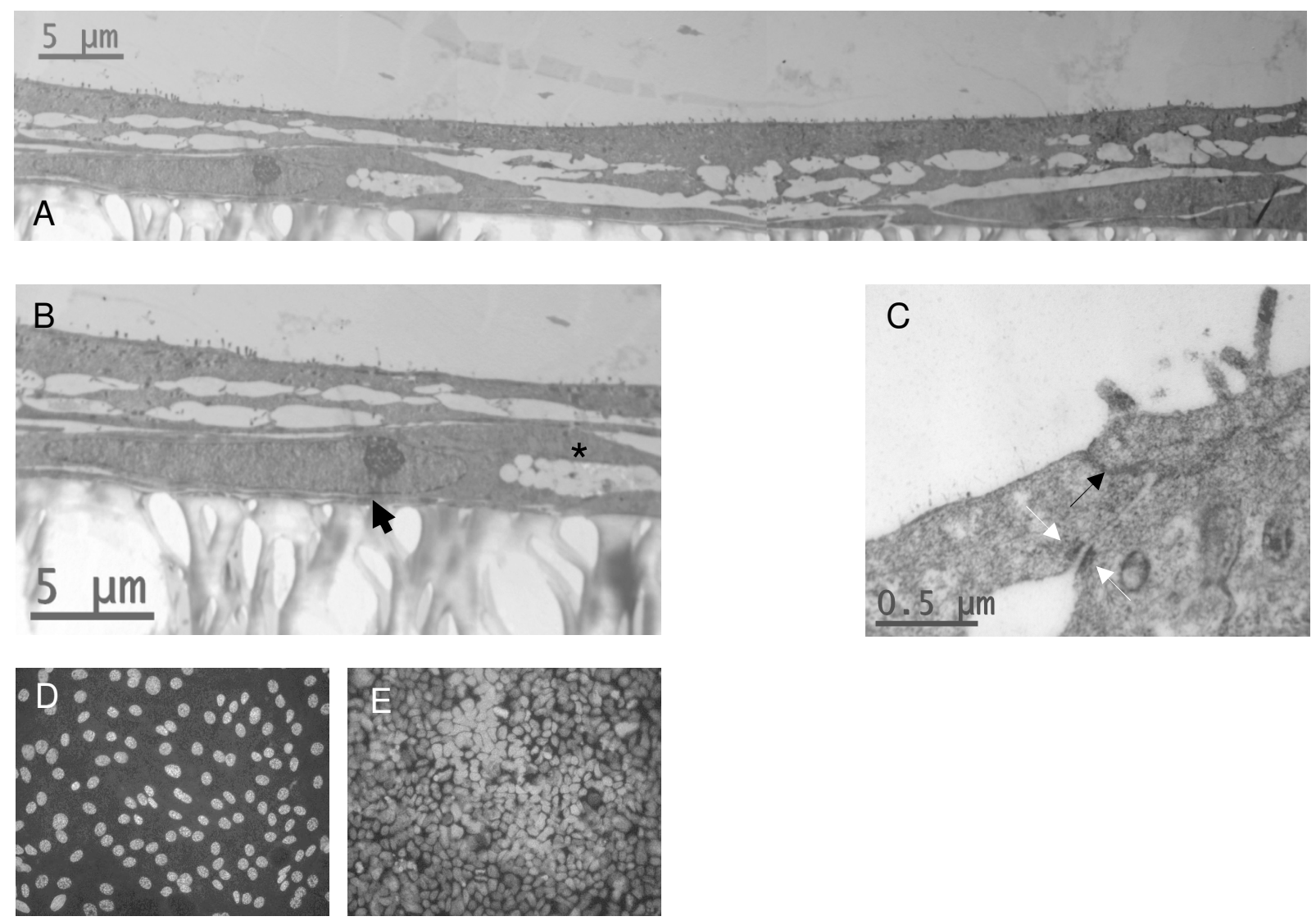

Fig. 4 
Fig. 5

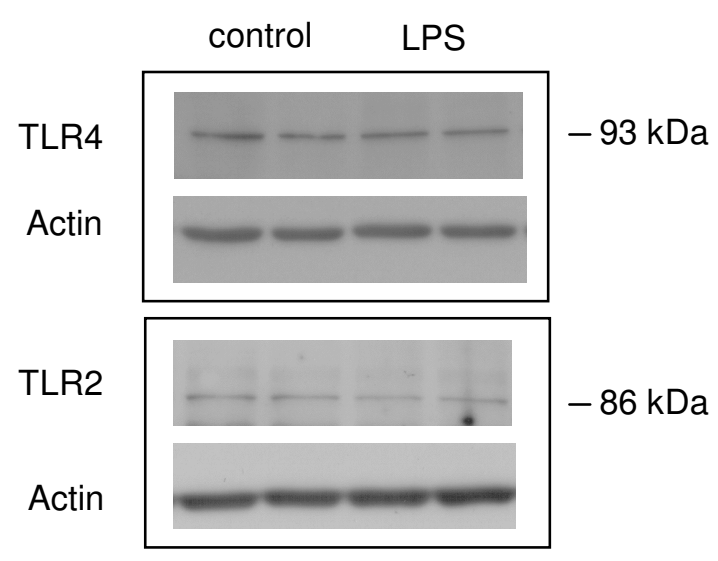

http://mc.manuscriptcentral.com/INI 
Fig. 6
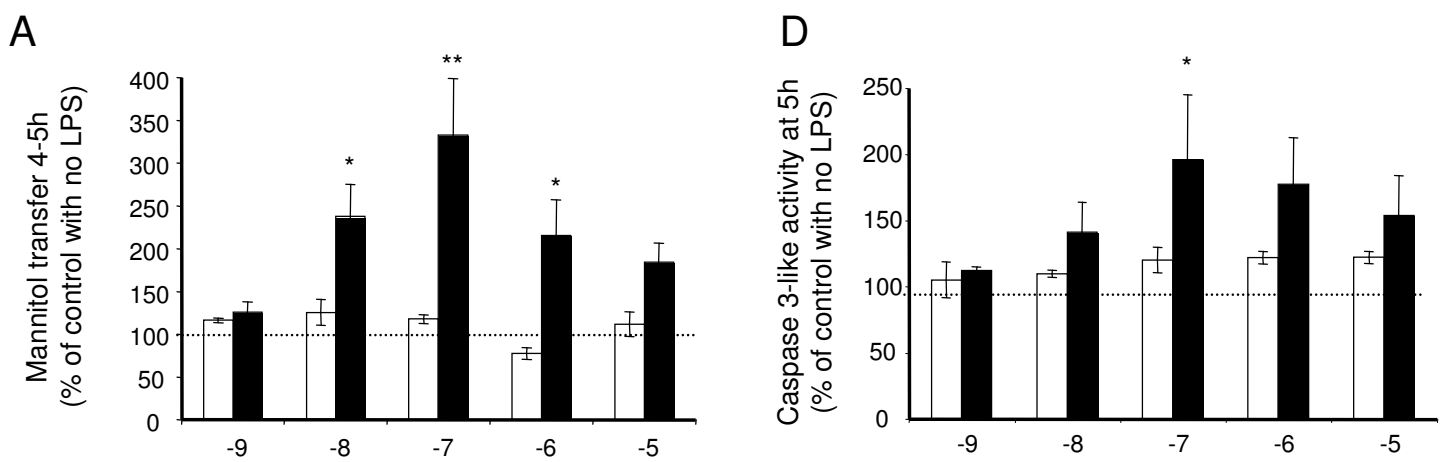

B

$\log \{$ LPS concentration $(\mathrm{g} / \mathrm{ml})\}$

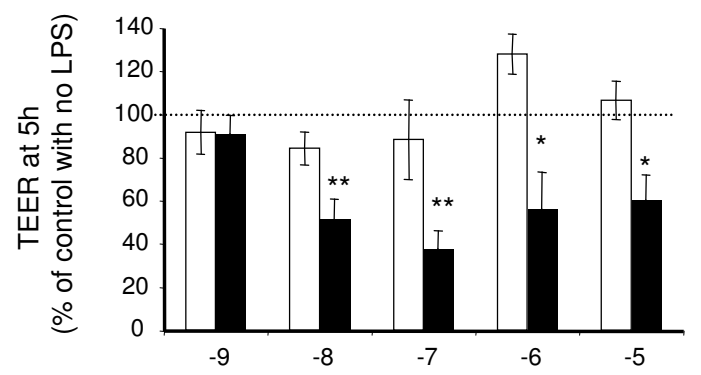

$\log \{$ LPS concentration $(\mathrm{g} / \mathrm{ml})\}$
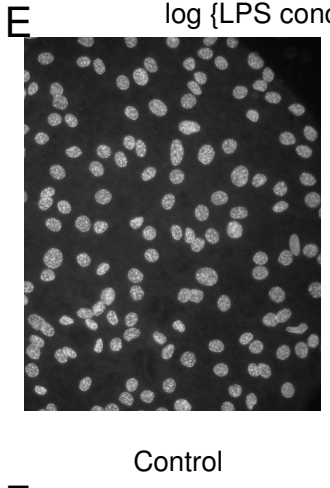

$\mathrm{F}$

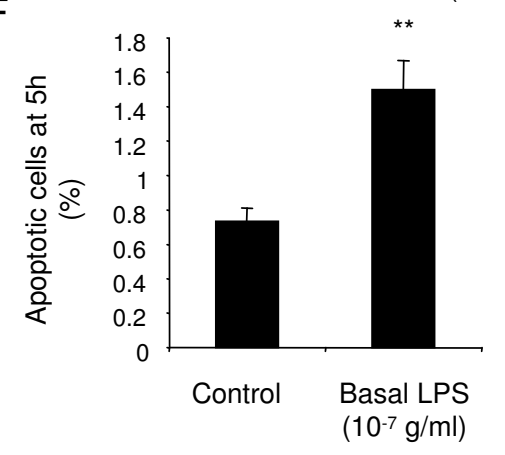


Fig. 7

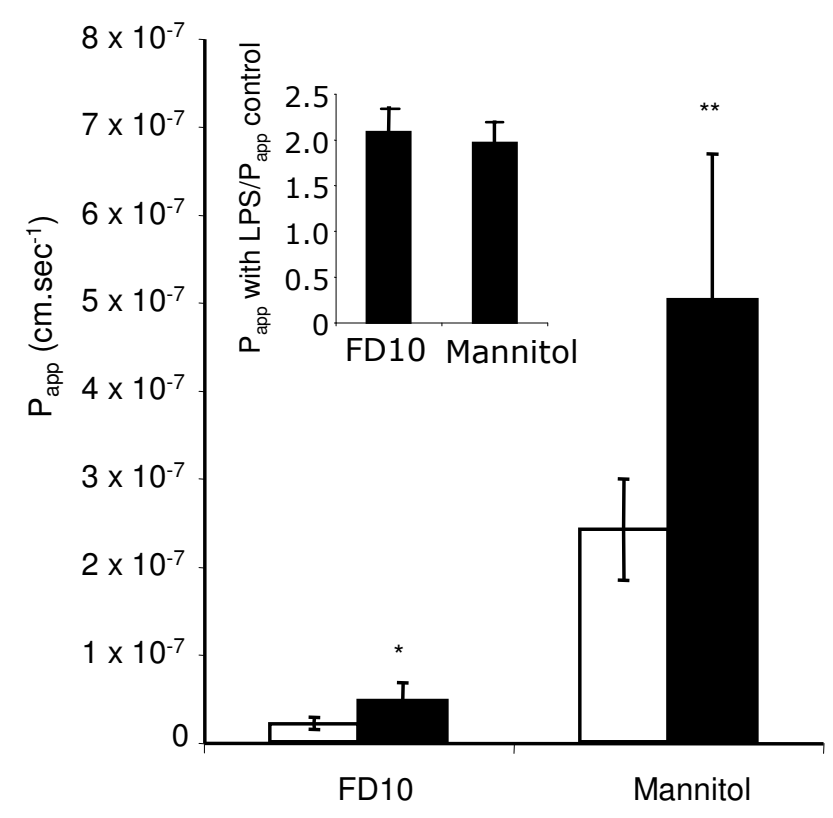

http://mc.manuscriptcentral.com/INI 
Fig. 8
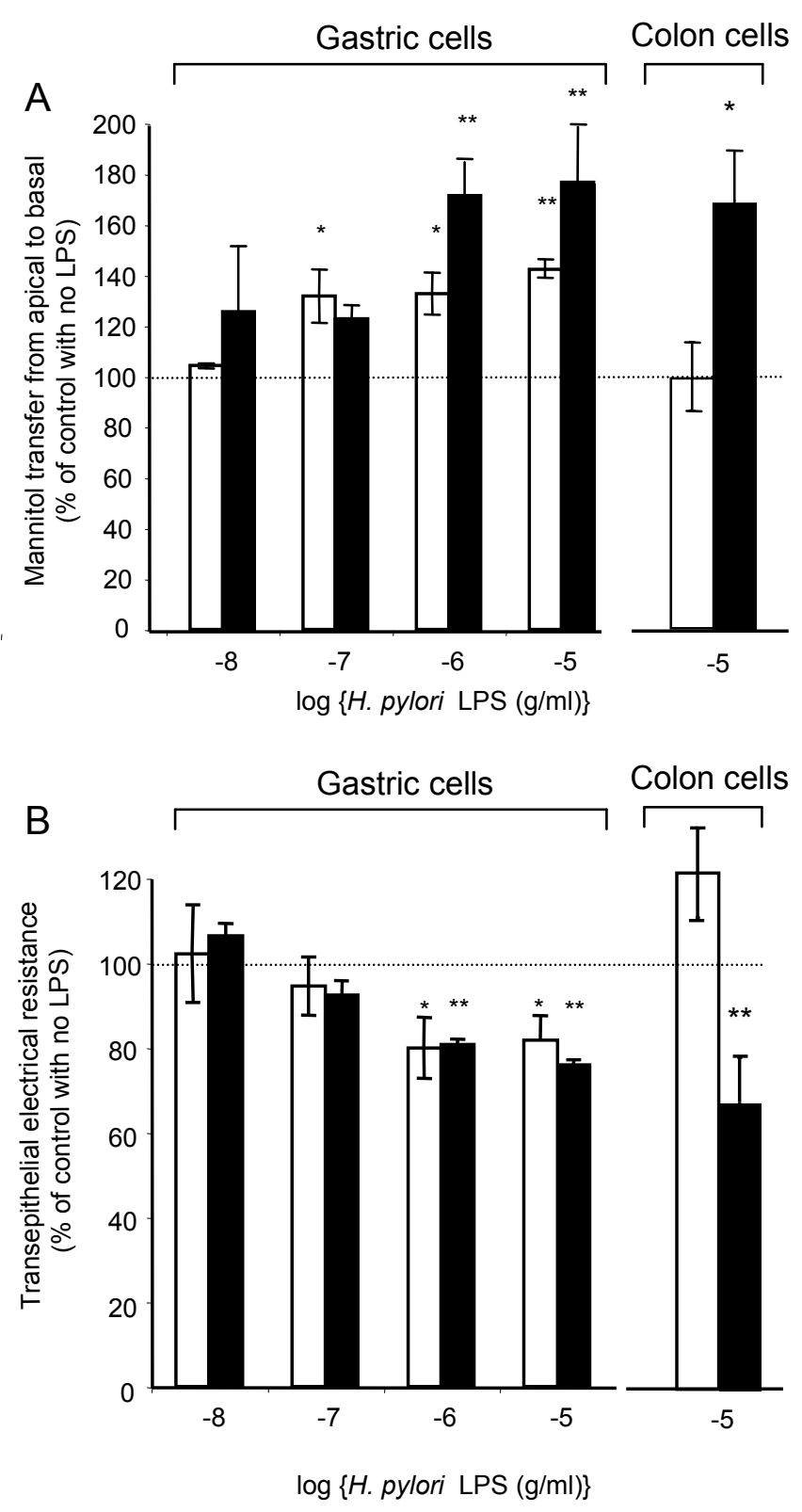

http://mc.manuscriptcentral.com/INI 
Fig. 9

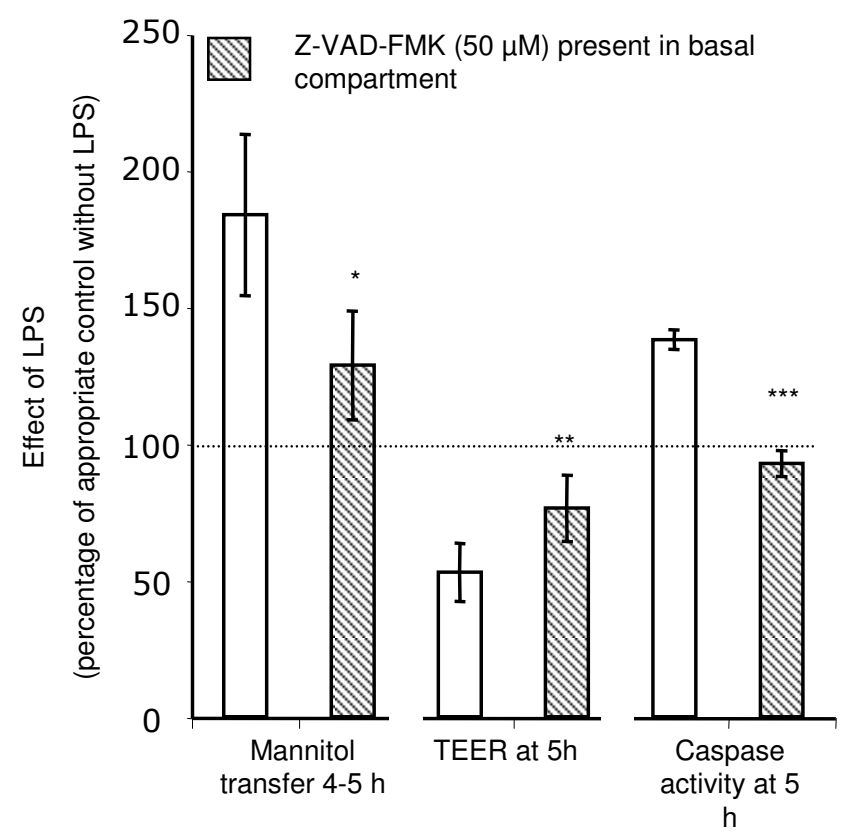

http://mc.manuscriptcentral.com/INI 
Fig. 10
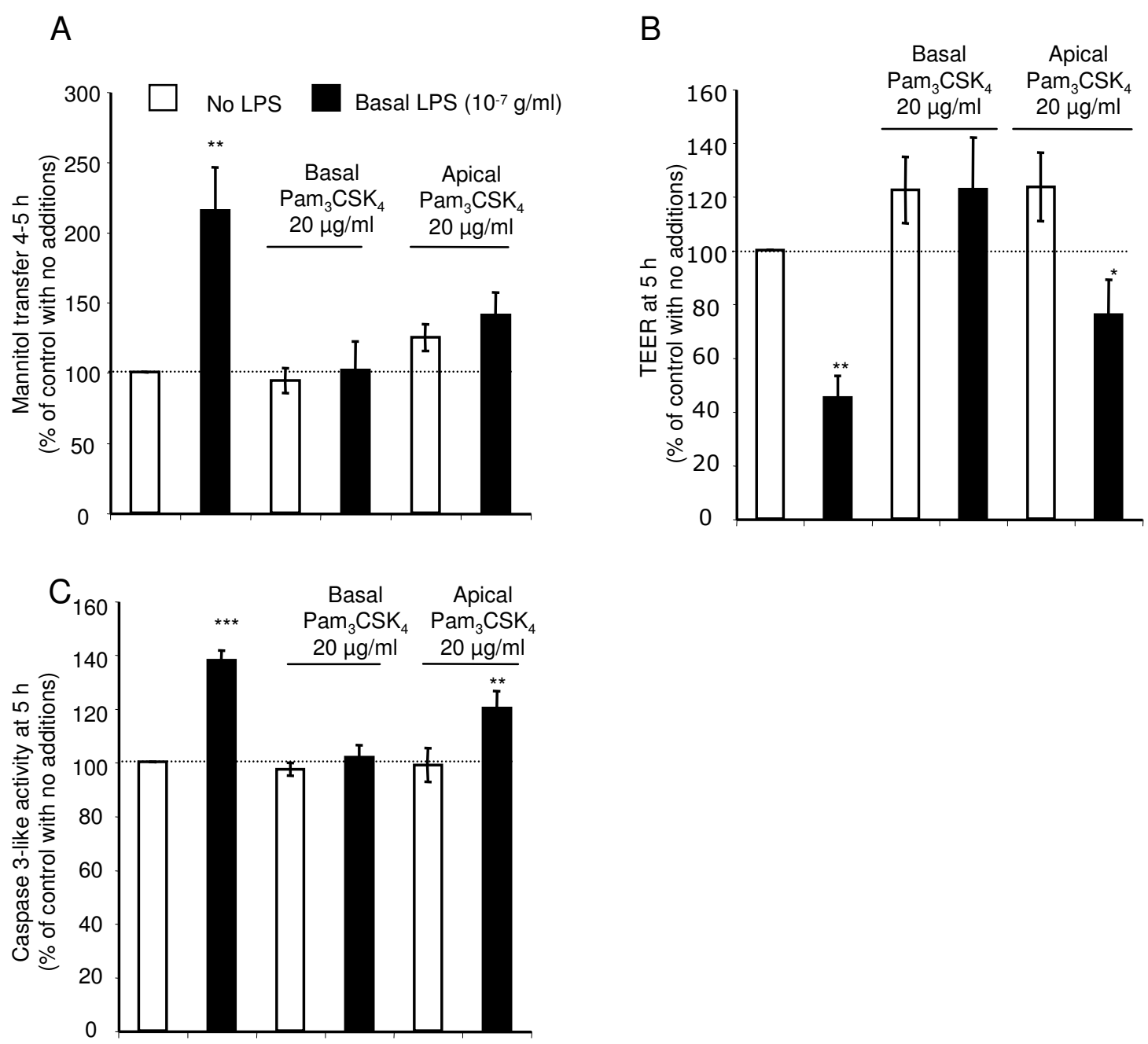